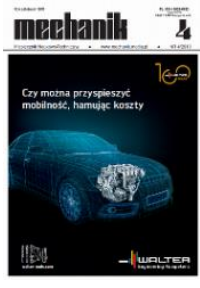

How to cite this article:

Authors: Marcin Snopczyński, Jarosław Kotliński, Ireneusz Musiałek

Title of article: „Testing of mechanical properties of materials used in FDM technology”

Mechanik, No. 4 (2019)

DOI: https://doi.org/10.17814/mechanik.2019.4.37

\title{
Testing of mechanical properties of materials used in FDM technology
}

\author{
MARCIN SNOPCZYŃSKI \\ JAROSŁAW KOTLIŃSKI \\ IRENEUSZ MUSIALEK *
}

Mgr Marcin Snopczyński (m.snopczynski@uthrad.pl), https://orcid.org/0000-0001-8537-907X - Wydział Mechaniczny, Uniwersytet Technologiczno--Humanistyczny im. Kazimierza Pułaskiego, Radom, Polska

Dr inż. Jarosław Kotliński (j.kotlinski@uthrad.pl), https://orcid.org/0000-0001-8545-3348 - Wydział Mechaniczny, Uniwersytet Technologiczno-Humanistyczny im. Kazimierza Pułaskiego, Radom, Polska

Dr inż. Ireneusz Musiałek (ireneusz1981@wp.pl), https://orcid.org/0000-0002-6069-0803 - Wydział Zamiejscowy w Sandomierzu Uniwersytetu Jana Kochanowskiego w Kielcach, Sandomierz, Polska

With the development of 3D printing technology, there is a development in the use of new printing materials. In practice, it often happens that the constructor does not have full data about the material that he wants to use. The article presents the results of tests of tensile strength of samples printed using the FDM method. 3D printing using the FDM method is widespread, however, the properties of the materials used in this method are still not fully understood. The aim of the research was to obtain information on strength parameters that form the basis for further analyzes.

KEYWORDS: 3D printing, strengthtests, FDM

\section{Introduction}

FDM is a popular 3D printing method (e.g. in the case of machine elements manufacturing) due to the wide range of properties of available materials [1-4] and low prices of printers used in this method.

To be able to take full advantage of the properties of materials, one must first get to know them well. Information on material properties does not contain data on how to prepare samples for testing these properties. Samples intended for testing can be printed with different parameters, and thus may have different internal structure. For these reasons, standardized samples were tested - material properties determined in this way will be a reference point in further research on 3D printed cellular structures.

The following materials were selected for strength tests: PLA, PETG, smart ABS, PLA PRO, HIPS, ASA, polycarbonate (PC-IN), Nylon (PA12) and nanocarbon (PA12+CF).

\section{Preparation of samples for strength tests}

Samples for strength tests were prepared in accordance with PN-EN ISO 527-2: 2012 [5]. Sample models were created in Autodesk Inventor 2018 and saved in .stl file format. Fig. 1 shows the shape of the sample with its characteristic dimensions.

Model of each printed sample was set on the $X$ axis (fig. 2). Data of the filaments, from which the samples were printed (fig. 3), are summarized in tab. I. 


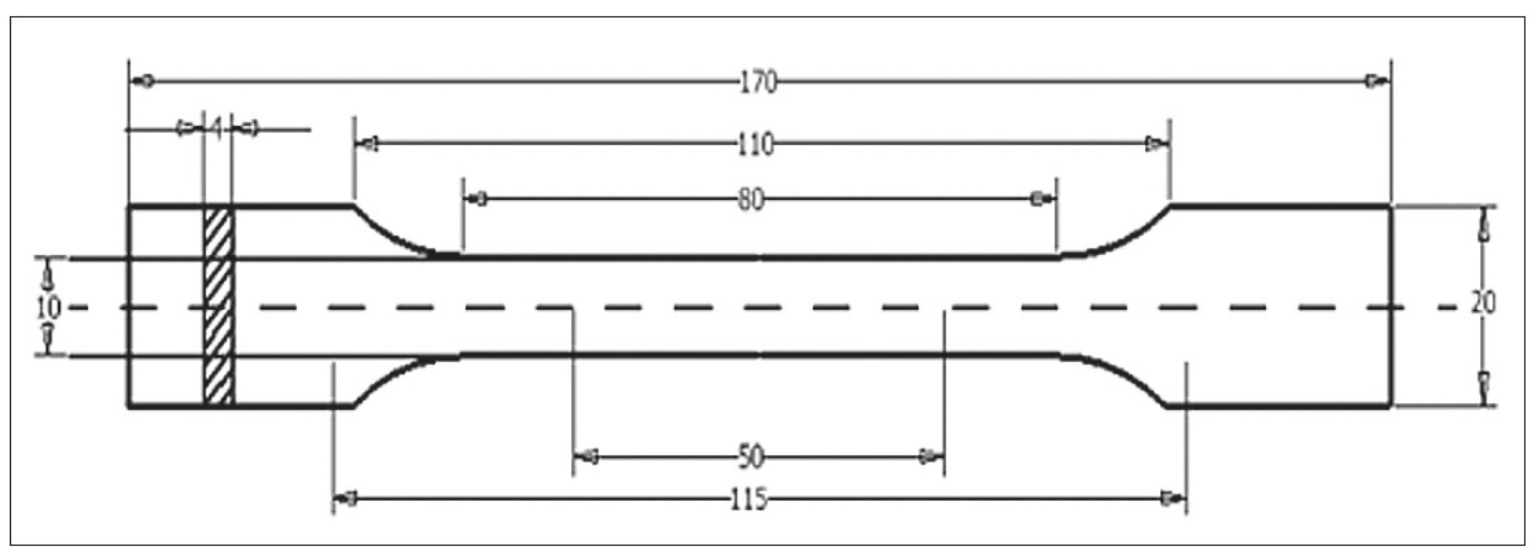

Fig. 1. Sample for strength tests

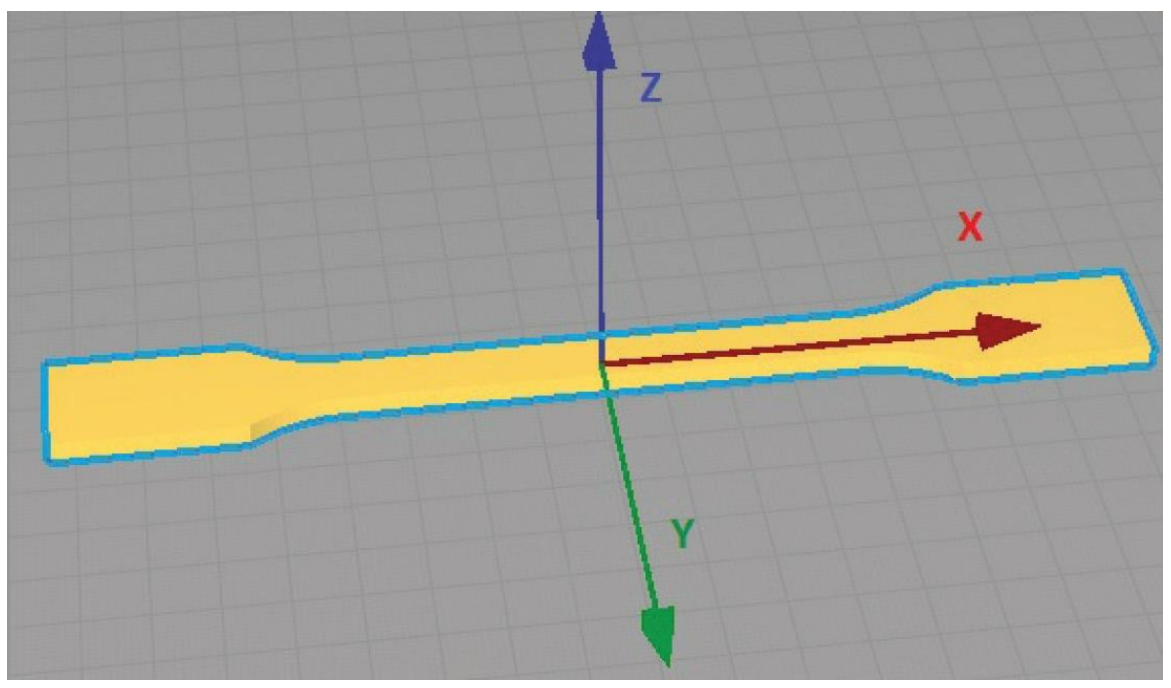

Fig. 2. Setting the sample on the 3D printer table - orientation relative to the $X$ axis

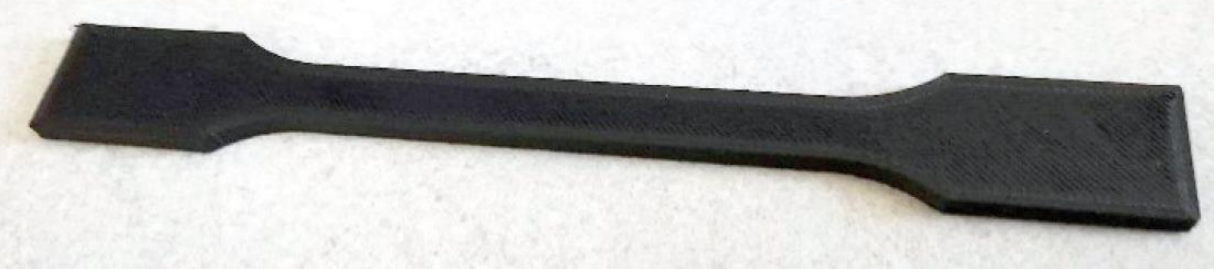

Fig. 3. Sample for strength tests printed by the FDM method

TABLE I. List of optimal print parameters for the materials used

\begin{tabular}{|c|c|c|c|c|c|c|c|c|c|}
\hline Filament & $\begin{array}{c}\text { PLA } \\
\text { Devil } \\
\text { Design }\end{array}$ & $\begin{array}{c}\text { PLA PRO } \\
\text { Spectru } \\
m\end{array}$ & $\begin{array}{c}\text { Smart } \\
\text { ABS } \\
\text { Spectrum }\end{array}$ & $\begin{array}{c}\text { PETG Devil } \\
\text { Design }\end{array}$ & $\begin{array}{c}\text { ASA Devil } \\
\text { Design }\end{array}$ & $\begin{array}{c}\text { HIPS } \\
\text { ArtFlex }\end{array}$ & $P C-I N$ F3D & $\begin{array}{c}\text { NANOCARB } \\
\text { ON F3D }\end{array}$ & $\begin{array}{c}\text { NYLON } \\
\text { FIBERLOG } \\
Y\end{array}$ \\
\hline $\begin{array}{c}\text { Head } \\
\text { temperature }\end{array}$ & $190^{\circ} \mathrm{C}$ & $205^{\circ} \mathrm{C}$ & $235^{\circ} \mathrm{C}$ & $230^{\circ} \mathrm{C}$ & $240^{\circ} \mathrm{C}$ & $245^{\circ} \mathrm{C}$ & $260^{\circ} \mathrm{C}$ & $250^{\circ} \mathrm{C}$ & $260^{\circ} \mathrm{C}$ \\
\hline $\begin{array}{c}\text { Table } \\
\text { temperature }\end{array}$ & $50^{\circ} \mathrm{C}$ & $50^{\circ} \mathrm{C}$ & $95^{\circ} \mathrm{C}$ & $75^{\circ} \mathrm{C}$ & $95^{\circ} \mathrm{C}$ & $95^{\circ} \mathrm{C}$ & $110^{\circ} \mathrm{C}$ & $115^{\circ} \mathrm{C}$ & $120^{\circ} \mathrm{C}$ \\
\hline $\begin{array}{c}\text { Material } \\
\text { feed speed }\end{array}$ & $35 \mathrm{~mm} / \mathrm{s}$ & $35 \mathrm{~mm} / \mathrm{s}$ & $30 \mathrm{~mm} / \mathrm{s}$ & $35 \mathrm{~mm} / \mathrm{s}$ & $35 \mathrm{~mm} / \mathrm{s}$ & $35 \mathrm{~mm} / \mathrm{s}$ & $25 \mathrm{~mm} / \mathrm{s}$ & $25 \mathrm{~mm} / \mathrm{s}$ & $25 \mathrm{~mm} / \mathrm{s}$ \\
\hline Cooling & $\begin{array}{c}\text { First layer } \\
20 \% \text { next } \\
100 \%\end{array}$ & $\begin{array}{c}\text { First layer } \\
20 \% \text { next } \\
100 \%\end{array}$ & No cooling & $\begin{array}{c}\text { First layer } \\
0 \% \text { kolejne } \\
20 \%\end{array}$ & No cooling & No cooling & No cooling & No cooling & No cooling \\
\hline
\end{tabular}

Samples were made on the Anycubic i3 Mega 3D printer, for which a normalized machine code (G-code) was created in Cura 3.51. Filling of the samples constituted $100 \%$ of the material, assuming that the coating of each sample had an outer wall of $1.2 \mathrm{~mm}$ thick, made by three strokes of the print head, and the center was made up of fibers in the form of printed lines arranged at an angle of $45^{\circ}$. 
Four samples were printed for each material. In tab. I, the optimal print parameters adopted for each material in accordance with the manufacturer's recommendations are presented. For all prints: $1.75 \mathrm{~mm}$ filament, $0.4 \mathrm{~mm}$ nozzle; the layer height $0.2 \mathrm{~mm}$, was applied [6].

\section{Research}

Determination of strength properties was carried out on the basis of a static tensile test using a Labor Tech Lab Test 6.20 testing machine. The test conditions were in accordance with the PN-EN ISO 527-2: 2012 standard.

As a result, strength parameters of selected materials were determined, such as: maximum tensile stress, yield strength, modulus of elasticity and stress-elongation relationships.

\section{Results and analysis}

The test results are presented in tab. II. For each material: maximum breaking force, relative elongation at break, yield point, relative elongation at yield, and modulus of elasticity, are given. All samples had the same initial cross-sectional area, therefore it was possible to determine the breaking strength for each material. In addition, the maximum breaking stress was determined.

Fig. 4 presents selected samples after rupture. Fig. 5 shows a graph of tensile force as a function of elongation.

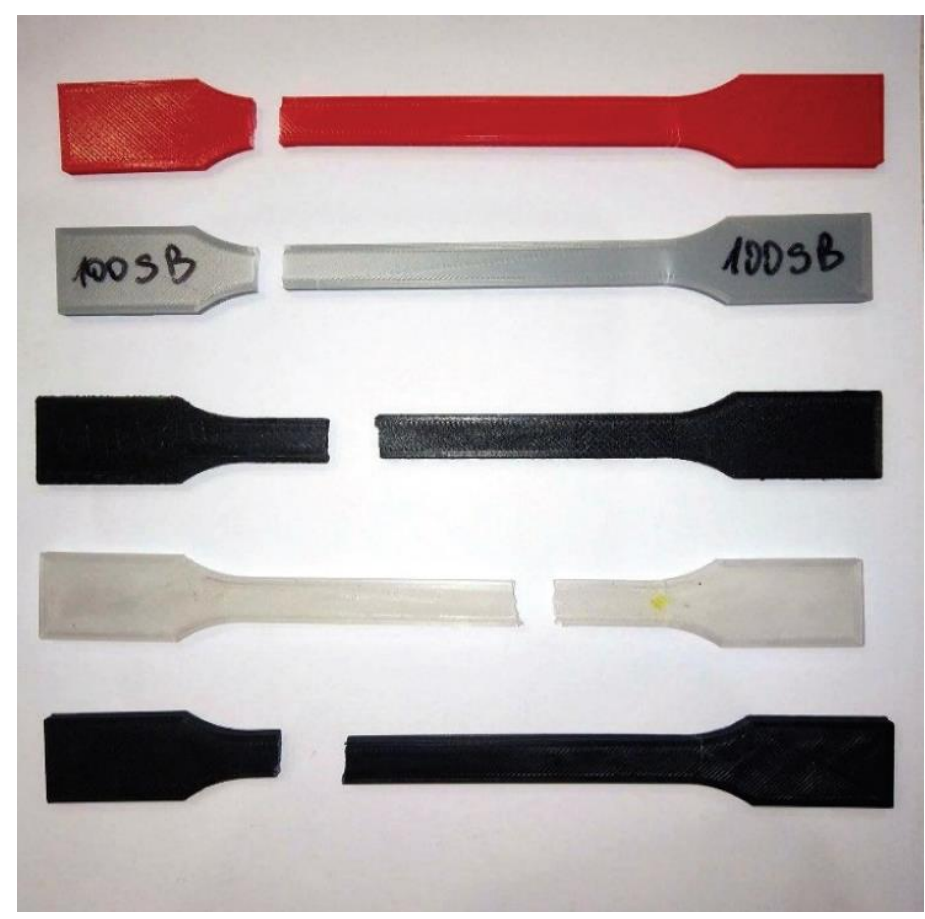

Fig. 4. Selected samples after rupture - from above: PLA PRO, smart ABS, nanocarbon, PC-IN polycarbonate, ASA

TABLE II. List of optimal print parameters for each material

\begin{tabular}{|c|c|c|c|c|c|c|}
\hline Material & $\begin{array}{l}\text { Breaking force } \\
\text { value [N] }\end{array}$ & $\begin{array}{c}\text { Tensile strength } \\
{[\mathrm{MPa}]}\end{array}$ & $\begin{array}{c}\text { Relative } \\
\text { elongation at } \\
\text { break } \\
{[\mathrm{mm}]}\end{array}$ & Yield point [N] & $\begin{array}{c}\text { Relative } \\
\text { elongation at yield } \\
\text { point }[\mathrm{mm}]\end{array}$ & $\begin{array}{l}\text { Modulus of } \\
\text { elasticity [GPa] }\end{array}$ \\
\hline HIPS & 391,58 & 9,79 & 4,88 & 127,16 & 0,19 & 31,25 \\
\hline NYLON & 1420,66 & 35,52 & 13,12 & 1384,08 & 4,94 & 23,31 \\
\hline SmartABS & 1875,64 & 46,89 & 3,65 & 0 & 0 & 8,59 \\
\hline PLA PRO & 1889 & 47,23 & 5,52 & 43,98 & 0,15 & 10,29 \\
\hline ASA & 1903,28 & 47,58 & 4,8 & 0 & 0 & 4,97 \\
\hline PETG & 2222,54 & 55,56 & 5,325 & 70,1 & 0,28 & 18,83 \\
\hline PLA & 2303,56 & 57,59 & 6,485 & 42,72 & 0,19 & 5,59 \\
\hline Polycarbonate & 2572,12 & 64,30 & 6,04 & 0 & 0 & 0,52 \\
\hline NANOCARBON & 3002,68 & 75,07 & 5,49 & 2970,4 & 5,04 & 0,62 \\
\hline
\end{tabular}


Fig. 5. Graph of tensile force as a function of elongation

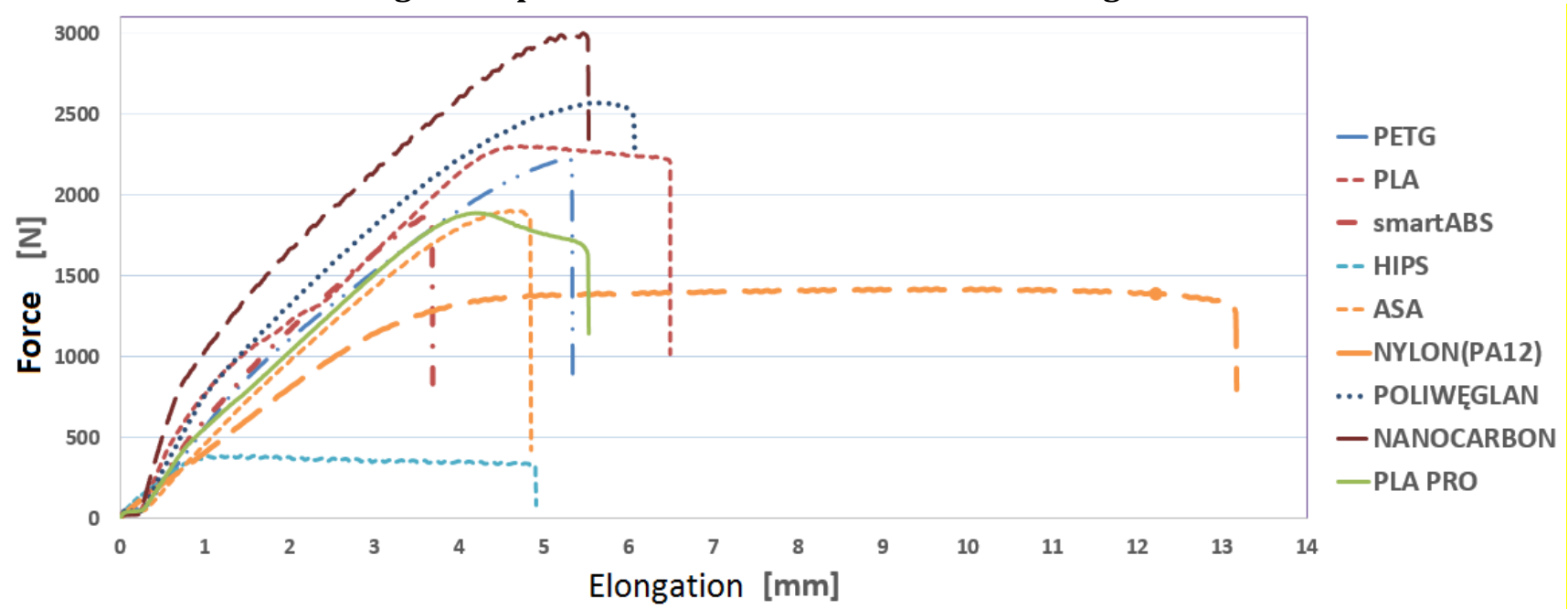

Based on the analysis of test results, it can be concluded that nanocarbon, that is a combination of nylon and carbon fiber, has the highest breaking strength. PC-IN polycarbonate is another very durable material, the strength of this material is $14 \%$ lower than that of nanocarbon. In addition, there are two groups of materials with very similar strength:

- PLA and PETG with 23-26\% less strength than nanocarbon,

- smart ABS, ASA and PLA PRO with 37\% less strength than nanocarbon.

PA12 nylon strength is more than half as compared to nanocarbon.

Nylon was the most elongated during the tensile test. The elongation of this material was more than double that of other materials. In turn, smart ABS has the smallest extension. The elongation of smart ABS was only $27 \%$ elongation of nylon.

Smart ABS, ASA and PC-IN polycarbonate materials are brittle, therefore the yield strength of these materials could not be determined.

PLA PRO material has twice the elasticity and 18\% less strength compared to PLA.

\section{Conclusions}

All samples were tested according to the same methodology, in accordance with PN-EN ISO 527-2: 2012, therefore the results obtained for individual materials are comparable.

As expected, nanocarbon (75 $\mathrm{MPa}$ ) has the highest tensile strength; at the same time, it has one of the smallest modulus of elasticity ( $0.62 \mathrm{GPa})$. PC-IN polycarbonate, similar to nanocarbon, with tensile strength of $64 \mathrm{MPa}$ and the smallest of the tested materials, has the modulus of elasticity $0.52 \mathrm{GPa}$. Both materials can be used to build high-strength machine parts.

PLA and PETG materials have similar tensile strength - $58 \mathrm{MPa}$ and $56 \mathrm{MPa}$, respectively. However, where greater elasticity is required, PETG should be used, since this material has nearly 3.4 times greater modulus of elasticity than PLA, which is $19 \mathrm{GPa}$.

HIPS has the lowest tensile strength (10 MPa) - commonly used as a support material when printing with $\mathrm{ABS}$. It has the largest modulus of elasticity of all tested materials - in the order of $31 \mathrm{GPa}$.

The obtained results were in line with expectations and can be used to select materials for the construction of machine parts (where tensile strength is an important parameter) and as a base and reference point for further research.

Samples of materials printed at the highest working temperatures of the print head and the working table have better mechanical properties and have higher tensile strength than other materials.

\section{REFERENCES}

[1] http://centrumdruku3d.pl/ (access: 24.02.2019). 
[2] Farhad Mohammad Othman, Tahseen Fadhil, Abbas Hind Basil Ali. "Influence of process parameters on mechanical properties and printing time of FDM PLA printed parts using design of experiment". Journal of Engineering Research. ISSN: 2248-9622. 8, 7 (Part II: July 2018): 65-69.

[3] Tahseen Fadhil Abbas, Farhad Mohammad Othman, Hind Basil Ali. "Effect of infill parameter on compression property in FDM process". Journal of Engineering Research and Application. ISSN: 22489622. 7, 10, (Part I: November 2017): 16-19.

[4] Kotliński J. „Drukowanie części maszyn”. Radom: Wydawnictwo UTH, 2018.

[5] https://www.simplify3d.com/support/materials-guide/properties-table/ (access: 24.02.2019).

[6] PN-EN ISO 527-2:2012. Tworzywa sztuczne - Oznaczanie właściwości mechanicznych przy statycznym rozciąganiu - Część 2: Warunki badań tworzyw sztucznych przeznaczonych do różnych technik formowania. 